\title{
Facilitating the restoration of aquatic plant communities in a Ramsar wetland
}

Running head:Facilitating wetland restoration

Authors and Addresses:

Dr Sacha Jellinek ${ }^{1,2}$, Thai $\mathrm{Te}^{2}$, DrSusan Gehrig ${ }^{3}$, Hafiz Stewart $^{2}$,Dr Jason Nicol ${ }^{3}$

${ }^{1}$ sacha.jellinek@gmail.com

${ }^{2}$ Vegetation Program, Partnerships and Stewardships, Department of Environment, Water and Natural Resources, 101 Grenfell St, Adelaide South Australia 5000.

${ }^{3}$ South Australian Research \& Development Institute, Aquatic Sciences, West Beach, Adelaide South Australia 5024.

\section{Author contributions}

SJ, TT, HS conceived this research; SG, JN designed the survey method and undertook the surveys; SJ, JN undertook the analysis of the data; SJ wrote the manuscript; JN, SG, HS, TT edited the manuscript; SJ completed subsequent revisions to the manuscript

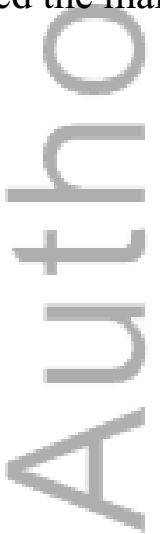

This is the author manuscript accepted for publication and has undergone full peer review but has not been through the copyediting, typesetting, pagination and proofreading process, which may lead to differences between this version and the Version of Record. Please cite this article as doi: $10.1111 /$ rec.12355

This article is protected by copyright. All rights reserved. 


\begin{abstract}
Human activities such as land clearing and intensive land use around water bodies, particularly wetlands, have a detrimental impact on water quality and quantity, aquatic plant communities and associated wetland fauna. Lake Alexandrina and Lake Albert are internationally significant Ramsarwetlands located at the terminus of the Murray River, Australia's longest river system. Agriculture, water regulation and extraction and droughts have had a detrimental impact on native plant communities in the lakes. We studied the influence of young ( $<1-3$ years) and old ( 8 - 11 years) plantings of a native sedge (bulrush), Schoenoplectus tabernaemontani, to facilitate the establishment of aquatic plant communitiesin comparison to remnant and control sites. We also measured how planting structure (height, stand width and stem density) changed with age in comparison to remnant sites. Results suggest that as plantings age they get substantially wider and have a greater maximum height, although do not reach similar stand widths by 11 years of age when compared to remnant areas. However, old plantings do not differ from remnant habitats in relation to aquatic plant species richness, counts of aquatic plants and community composition. Young plantings have substantially less abundant and diverse plant communities, but are developing on a similar trajectory to old plantings. It is likely that planting sedges along lake shorelines causes a breakwater effect that facilitatesthe recolonization of wetland plants between the planted area and the water's edge.Management agencies should consider restoring native sedges to increase aquatic biodiversity, and potentially reduce erosion.
\end{abstract}


Keywords: Restore, wetlandflora, sedge,river club-rush, community composition, planting structure.

\section{Implications:}

- The planting of large aquatic plant species, such as sedges,can assist native aquatic plant communities to recolonize lake shorelines, increasing the resilience of Ramsar

listed habitats and other wetlands.

- Sedge plantings are likely to provide greater shoreline protection as they get older as plantings expand and become structurally more complex as they age.

- Practitioners trying to restore aquatic plant communities after wetland degradation, as a result of drought or livestock grazing, should seekto create a breakwater effect between the restored area and the shoreline so sediment can settle and other plants can become established in this low energy zone.

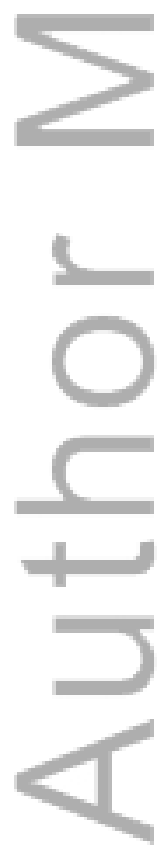

This article is protected by copyright. All rights reserved. 


\section{Introduction}

The health and persistence of wetlands around the world have continually declined as a result of anthropogenic disturbance in human-dominated landscapes, despite global agreements such as the Ramsar Convention (1971) to protect threatened ecosystems(Matthews 1993; Hettiarachchi et al. 2015).Impacts on wetlands from human influences includeurban development and/or agricultural intensification, pollution, structural degradation, vegetation clearance and excessive water extraction (Bond \& Lake 2003; Bond et al. 2008; Pander \& Geist 2013). These impacts are often exacerbated by natural processes such as long-term droughts(Bond et al. 2008).

Droughts can cause standing water to reduce or dry up and as water levels recede ecologically diverse littoral communities decline or can become locally extinct(Bond et al. 2008). Grazing by livestock usually intensifies this loss of littoral vegetation (Vanderbosch \& Galatowitsch 2011; Pander \& Geist 2013). Littoral zones are important because they provide a niche for ecologically diverse communities, and littoral vegetation also functions as a natural breakwater to shorelines by decreasing wave attenuation(Augustin et al. 2009; Gedan et al. 2011).Without this, whenwater levels return wave energy can cause shoreline erosion and reduce the likelihood that aquatic plant species will become established (Vanderbosch \& Galatowitsch 2010; Gedan et al. 2011), decreasing potential habitats for fish, invertebrates and birds (Vanderbosch \& Galatowitsch 2010). Subsequently, aquatic macrophytes such as sedges may not re-establish naturally and thus require interventions such as replanting (Vanderbosch \& Galatowitsch 2010; Pander \& Geist 2013). 
Restoration of physical habitats has often accompanied the degradation of these aquatic systems and has been used widely as a tool to improve water quality andre-establish biological diversity and thus habitat heterogeneity (Bond \& Lake 2003) while also having many positive social outcomes (Bernhardt \& Palmer 2011; Pander \& Geist 2013). However,little research or monitoring exists to show how effective habitat restoration in aquatic systems is for increasing biodiversity(Chapman \& Underwood 2000; Bond \& Lake 2003; Bernhardt et al. 2007)and previous studies mainly focus on the use of aquatic plantings for wastewater treatment (Tanner 1994; Zhang et al. 2007; Pollard 2010). This can result in expensive restoration activities that may have limited ecological benefits or social outcomes(Bernhardt et al. 2005). Similarly, little is known about the most effectivemethods to re-establish wetland vegetation to maximise survival of native plant communities(Vanderbosch \& Galatowitsch 2011). Re-establishing aquatic vegetation is especially difficult in countries such as Australia, where many water bodies are ephemeral and where droughts can persist for long periods of time (Bond et al. 2008).

This research aimed to assess the benefits or negative impacts of planting a native, noninvasive sedge species, Schoenoplectustabernaemontani, on the aquatic plant communities of two large,Ramsar listed freshwater lakes, Lake Alexandrina and Lake Albert, in South Australia. Our project aimed to investigate: (i) how the structure of planted S. tabernaemontanistands (stand width, maximum and average stem height and stem density) of different ages (young plantings and old plantings) changed over time compared to remnant (naturally occurring) stands, and (ii) the influence of planted S. tabernaemontanistands of different ages (young plantings and old plantings) on aquatic plant community composition in 
comparison to control sites and remnantareas. By making these comparisons we aimed to discover whether young plantings had a different structure to old plantings, how the structure of young and old plantings compared to that of remnant stands, and how the age of $S$. tabernaemontani stands influenced aquatic plant community composition. This information is valuable for determining the effectiveness of planting native sedge species for maintaining and increasing aquatic plant communities in freshwater lakes and associated water bodies.

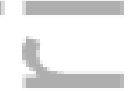

\section{Methods}

\section{Species description}

Schoenoplectus tabernaemontani (C.C.Gmel.) Palla (syn. Schoenoplectus validus (Vahl) A. Love \& D. Love; Scirpus tabernaemontani Vahl), locally known as the river club-rush,is a large, perennial, rhizomatous sedge (bulrush) that grows $2-3 \mathrm{~m}$ in height (up to $5 \mathrm{~m}$ in very favorable conditions) in water up to $1.5 \mathrm{~m}$ depth (Sainty \& Jacobs 2003). It is native to Australia and many other parts of the world. Ecosystem services provided by

S. tabernaemontani include erosion control, waterbird habitat, fish habitat, sediment and water column aeration and water quality improvement (Sainty \& Jacobs 2003). It is a common emergent species around the edges of freshwater and brackish lakes, but unlike other large emergent plant species such as Phragmitesaustralis and Typha domingensis it does not form dense monospecific stands (Hudon et al. 2005; Gehrig et al. 2012).

Schoenoplectus tabernaemontani usually grows in deeper water than T. domingensis and P. australis(Sainty \& Jacobs 2003) and is often associated with submergent taxa such as 
Myriophyllum spp., Potamogeton spp., Ceratophyllum demersum and

Vallisneriaaustralis(Gehrig \& Nicol 2010; Nicol et al. 2013).

\section{Site description}

Lake Alexandrina and Lake Albert are located in South Australia at the end of Australia's longest river system, the Murray River (Fig 1). The lakes are large and shallow and contain fresh to brackish water. They have been listed, along with the Coorong, as a wetland of international importance under the Ramsar Convention(DEH 2000). The lakes originally joined the Coorong, a shallow saline lagoon stretching for more than $100 \mathrm{~km}$ along the South Australian coast, and the sea. However, due to excessive water extraction along the Murray River, barrages and locks were erected in the 1930s to maintain water levels and reduce saline water incursions into the lakes. These barriers kept water levels relatively static, influencing the vegetation growing in the lakes and increasing shoreline erosion. Several droughts, increasing salinity and ongoing water extraction along the river system had caused large losses of native plants and animals in the lakes and surrounding water bodies (van Dijk et al. 2013).

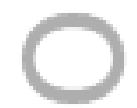

The Millennium Drought (1995 - 2009) greatly exacerbated these environmental impacts and also caused dramatic socioeconomic problems. The Millennium Drought was the worst hydrological drought since records began in the late $19^{\text {th }}$ century and caused surface water storages along the Murray-Darling Basin to decline by $73 \%$ and flows into Lake Alexandrina to cease(van Dijk et al. 2013). The impact of the drought were arguably most severe in the lower lakes region as water levels in Lake Alexandrina declined by approximately $2 \mathrm{~m}$, 
salinity levels rose to seven times higher than normal $(7000 \mu \mathrm{S} / \mathrm{cm})$ and the exposed lake bed started to release sulfuric acid(van Dijk et al. 2013). These impacts greatly reduced the number of aquatic plants around Lake Alexandrina and Lake Albert, and many of these shoreline communities have not recovered since the water started to return in $2010(\mathrm{~K}$. Strotherpers. comm.).

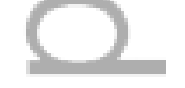

Schoenoplectus tabernaemontanioccurs naturally along the shorelines of Lake Alexandrina and Lake Albert and had been planted by community organisations since 1996 to reduce shoreline erosion (K. Strotherpers.comm.). After the Millennium Drought the Department of Environment, Water and Natural Resources (DEWNR) continued this work (2011 onwards) as S. tabernaemontanicould be planted in relatively deep water (up to $1 \mathrm{~m}$ depth), did not form dense homogenous stands and was thought to reduce erosion risk and increase shoreline biodiversity (Nicol et al. 2013). Initially S. tabernaemontaniwas propagated by taking remnant plant clumpsinto a nursery, dividing the clumpsinto individual stems and growing them in hessian pots. More recently nurseries germinated the plants from seed whichwere grown in individual pots, ready for transplanting when there were between $8-15$ stems present. Schoenoplectustabernaemontaniwasthen planted from November to Marcharound the lakes at $1 \mathrm{~m}$ intervalsin two offset rows in $50-80 \mathrm{~cm}$ of water at least $10 \mathrm{~m}$ from the shoreline; these offset rows extend for up to 1,000 m adjacent to the shoreline.

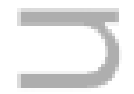

We surveyed 11 locations around Lake Alexandrina and Lake Albert between April - May in 2013, 2014 and 2015. At each location there were one or more survey sites and each site consisted of one of four treatment types. These four treatments were: (i) old plantings; (ii) 
young plantings; (iii) remnant areas and (iv) control areas.In total there were four old plantings;six young plantings; three remnant areas and eight control areas(Table S1, Fig 1). Old plantings were planted 8 - 11 years ago with one sedge species, S. tabernaemontani, and were planted as described above. Young plantings similarly contained S. tabernaemontani and were planted $<1-3$ years ago. Control sites were areas along the shoreline that had not been planted and lacked large sedge species. Control sites were on a similar aspect and substrate to old and young plantings and were usually more than $200 \mathrm{~m}$ away from planted sites. Generally one planted site was paired with a control site, although sites that contained both young and old plantings (Wellington Lodge and NurraNurra) shared a control site (Table S1). Remnant areas contained naturally occurring stands of S. tabernaemontaniand other sedge species and were generally considered to be 20 years of age or greater.A large proportion of the shorelines around Lake Alexandrina and Lake Albert had been fenced between 2010 and 2012, due to government incentives, to reduce livestock access on exposed sections of the lakebed. Therefore, all of the planted, control and remnant sites were fenced from livestock, reducing the possibility of these areas being disturbed or detrimentally impacted by grazing.

\section{Planting structure}

Planting structure in this case is the size, density and height of a distinct patch of planted S. tabernaemontaniand provides information on the rate of spread and health of the planted area. For this research, we collected data on the stem density, height of the tallest stem and the height of ten randomly selected stems using the method below.To determine the structure of S. tabernaemontanistands, we randomly placed five 1 x $1 \mathrm{~m}$ quadrats along one $100 \mathrm{~m}$ 
transect at each site of planted or remnant $S$. tabernaemontani(Fig 1, Fig 2). The placement was determined using five random numbers ranging from 1 - 100 (representing the length of a transect) that we randomly generated prior to going into the field. Within each quadrat we measured the stem density (number of stems), height of the tallest stem and the height of ten randomly selected stems. We also recorded thewidth of the S. tabernaemontanistand (referred to as 'stand width') at each quadrat by measuring from the outer edge of the quadrattowards the shoreline. Inplanted sections of S. tabernaemontaniwe surveyed along the two planted lines, whereas in remnant areas surveys were undertaken on the stand edge that was furthest from the shoreline.

\section{Community composition}

Using methodology developed to assess aquatic vegetation condition (Marsland \& Nicol 2008), we assessed community composition in the same $100 \mathrm{~m}$ section of shoreline in which the planting structure surveys had been undertaken in planted and remnant $S$.

tabernaemontanistands. At control sites a $100 \mathrm{~m}$ section of shoreline was randomly selected (Fig 2). Within this $100 \mathrm{~m}$ section,three transects were established in the middle and at either end perpendicular to the shoreline. At planted sites we recorded aquatic species that were between theplantings and the shoreline.Along each transect five depths were sampled: +0.8 , $+0.6,+0.4,+0.2$, and $0 \mathrm{~m}$ above sea level, based on the Australian Height Datum (AHD). The shorelines of Lake Alexandrina and Lake Albert are approximately $0.75 \mathrm{~m}$ AHD(Bureau of Meteorology 2015). Lower elevations were not surveyed due to the absence of vegetation. At each depth along each transect, three quadrats were established that were 1 x $3 \mathrm{~m}$ in size and separated by $1 \mathrm{~m}$ (Fig 2). All plants within each quadrat were identified to species level and 
their percent cover was estimated using a modified Braun-Blanquet scale(Braun-Blanquet 1932).

\section{Data analysis}

\section{Planting structure}

We analyzed theresponse of $S$. tabernaemontanistructureusing several simple linear regressionsfrom the lme4 package (Bates et al. 2014)in R(R Core Team 2014). Each of the four structural attributes: stem density; height of the tallest stem; height of ten randomly selected stems; and stand width were analyzed separately to determine the relationship between plant structure and planting age (young plantings $<1-3$ years of age, old plantings 8 - 11 years of age, and remnant areas that were all given an age of 20 years). In order to ensure that individual observations did not influence our results we used Cook's distance (Cook 1977) to examine the influence of outliers on regression coefficients, ensuring observations did not have a Cook's distance $>1.0$. The data from the three years of sampling were combined for this analysis and results were presented using ggplot2 (Wickham 2009) and included $95 \%$ confidence intervals (CI) of model coefficients.

\section{Community composition}

We used R (R Core Team 2014) and lme4(Bates et al. 2014)to perform a generalized linear mixed model with a Poisson distribution to analyze the relationshipbetween treatment type and species richness and counts of aquatic plants. A Poisson distribution was selected because our graphed data were consistent with the dispersal of count data(Hilborn \& Mangel 
1997). The $2.5^{\text {th }}$ and $97.5^{\text {th }}$ percentiles of the distribution were computed to provide $95 \% \mathrm{CI}$ for model coefficients. In this model we used treatment type (young planting, old planting, remnant or control) as a fixed effect with a random effect of site. Data were combined over the three years of sampling for each site. Residual plots did not reveal any obvious deviations from normality. Species richness was the total number of species recorded in between $0.6-0$ m AHD at each site, while counts of aquatic plantswere analogous to abundance and was calculated as the average number of each species recorded in between $0.6-0 \mathrm{~m} \mathrm{AHD}$ at each site. To maximize the likelihood that the species richness and counts of only aquatic plants was analyzed, we excluded species recorded at 0.8 AHDto reduce the number of terrestrial species.

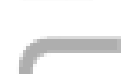

It was considered that independent variables would display 'some evidence' of a difference if the proportion of CI overlap was no more than half the average length of the two overlapping arms $(p<0.05)$, and the two overlapping arms did not differ in length by more than a factor of two(Cumming \& Finch 2005). Independent variables were considered to display 'quite strong evidence' of a difference if there was no overlap, or a gap between confidence intervals ( $p<0.01)$ (Cumming 2009; 2012).

In order to determine whether community composition of aquatic plant species was a function of site and treatmenttype (young planting, old planting, remnant and control), we used a cluster analysis in R (R Core Team 2014)using the vegan package(Oksanen et al. 2014). The species matrix was constructed using the total cover of each species recorded at a site. The cluster analysis included a Bray-Curtis dissimilarity measure, a widely used tool for 
analyzing community assemblage data, and a McQuitty similarity analysis(Crawley 2012).

We then used the metaMDS function in vegan to undertake non-metric multidimensional scaling (nMDS)(Anderson \& Ter Braak 2003).Similarly, this used a Bray-Curtis dissimilarity with 1,000 random starts, ending after two runs. An examination of the stress values showed that a two dimensional axis was sufficient to achieve low levels of stress for aquatic plant community composition ( stress $=0.132$ ). The indicator value for each species in a cluster was calculated using the indvalfunction (Dufrêne \& Legendre 1997) in the labdsv package (Roberts 2013).

\section{Results}

\section{Planting structure}

Analysis indicated a substantial increase in the stand width of S. tabernaemontani as plantings aged $\left(\mathrm{R}^{2}=0.49, \mathrm{p}=<0.001\right.$, Fig $\left.3 \mathrm{a}\right)$. We found that young plantings had a significantly lower stand width than old plantings, and that remnant sites were substantially wider than either young or old plantings. Similarly, the maximum height of S. tabernaemontanistemswas greatest in remnant areas $\left(\mathrm{R}^{2}=0.24, \mathrm{p}=<0.001\right.$, Fig $\left.3 \mathrm{~b}\right)$. While young plantings generally had lower maximum stem heights than old plantings or remnant areas, plantings around three years of age were more similar to old plantings than to other young planting sites. Eleven year old plantings also had a similar maximum stem height to remnant areas. The average height of $S$. tabernaemontanistems and stem density did not substantially differ between planted stands of different ages or planted stands and remnant areas (Table S2). 


\section{Community composition}

Our results suggested that species richness and counts of aquatic plants in control sites and young plantings were considerably lower than old plantings and remnant areas (Fig 4a, 4b).

Aquatic plant species richness showed some evidence of being lower in control sites compared to old plantings (mean expected difference $0.71,0.7-0.7495 \% \mathrm{CI}$ ) and quite strong evidence of being lower in control sites and young plantings compared to remnant sites (control sites - mean expected difference 1.06, 1.02 - $1.195 \% \mathrm{CI}$; young plantings mean expected difference $0.88,0.86-0.8995 \% \mathrm{CI}$ ). Counts of aquatic plants also showed quite strong evidence of being lower in control sites and young plantings compared to old plantings and remnant sites (control sites and old plantings - mean expected difference 1.18, 1.17 - $1.1895 \% \mathrm{CI}$; control and remnant sites - mean expected difference 1.51, 1.27 - 1.76 95\% CI; young and old plantings - mean expected difference 0.99, 0.98 - 1.00 95\% CI; young plantings and remnant sites - mean expected difference 1.33, 1.08 - 1.59 95\% CI) (Fig 4a, 4b, Table S3, Table S4). Variance for the random effect of site was small for both species richness $($ variance $=0.01)$ and counts of aquatic plants $($ variance $=0.06)$.

Community composition clustered into two main groups (Fig S1). The first cluster was composed of the control sites and young plantings, and one of the old plantings (NurraNurra). The second group was composed of remnant sites (Hindmarsh Island, Bremer River and Loveday Bay), old plantings (Dumandang, Raukkan and Wellington Lodge) and one young planting (Meningie Foreshore).Community composition of remnant areas was more similar to old plantings than either young plantings or control sites under a two-dimensionalsolution 
$($ stress $=0.132$, Fig 5$)$. There was a gradient of community composition complexity in the sites that we surveyed that ranged from common wetland plants in control sites and young plantings, to old plantings and remnant stands of S. tabernaemontani that contained a more diverse array of aquatic plant species (Fig 5, Table 1). This is supported by our analysis of the plant species most commonly associated with these clusters. This indicatedthat aquatic plants associated with early successional stages were found in the control sites and young plantings (cluster 1). These included semi-aquatic species such as Crassulahelmsii, Juncususitatusand Limosellaaustralis(Table 1). Plants associated with more established aquatic plant communities were found in old plantings and remnant areas (cluster 2) and consisted of species favoring calm water environments such as Azolla filiculoides, Myriophyllum salsugineum and Rumex bidens(Fig S1, Table 1).

\section{Discussion}

This study is novel in its research into planted sedge species and their importance in degraded wetland environments. Importantly, we found evidence thatSchoenoplectus tabernaemontaniallows otheraquatic plant species to colonize the zone between the planted area and the shoreline. This occurs quite rapidly, and after 11years the community composition in this zone starts to resemble remnant stands that have been established for 20 or morề years. Planted S. tabernaemontani stands also expand and multiply over time, and the widths of these stands are likely toexpand exponentiallywhere suitable habitats exist as time since planting increases. However, linear plantings of $S$. tabernaemontaniare unlikely to gain the width of remnant stands after 11 years of growth, even though the maximum height, 
average height and density of stems after the first few years of establishment is likely to be similar to remnant stands.

\section{Planting establishment and expansion}

Our results indicated that S.tabernaemontaniestablished relatively rapidly after planting, possibly because they were planted at a consistent depth $(50-80 \mathrm{~cm})$ over the summer months (November to March). This is consistent with other research on Schoenoplectus spp., which suggested that the timing of planting and planting depth were important factors to consider when restoring these sedge communities (Tanner 1996; Vanderbosch \& Galatowitsch 2010; 2011).High grazing pressure is also known to have a detrimental impact on the establishment of $S$. tabernaemontani(Tanner 1996)and persistence of soil seed bank(Erkkilä 1998), although this species may be able to re-establish after moderate grazing (Hayball \& Pearce 2004). All of our sites were fenced from livestock, reducing the likelihood that these plantings would be disturbed or detrimentally impacted (Vanderbosch \& Galatowitsch 2010).

\section{1}

The expansion of planted S. tabernaemontanisuggests that restoration activities that include the planting of this species are likely to provide shoreline protection in a relatively short amount of time, depending on the environmental factors present at a site. For example, Tanner (1996) found that S. tabernaemontanihad highly seasonal growth patterns with long periods of active growth compared to other aquatic plant species. Other studies havesuggested that environmental factors likely to influence reed bed expansion include seasonal fluctuations in water levels and nutrient influxes from the lake bottom and 
surrounding river systems(Liira et al. 2010; Catford et al. 2014). However, based on the response of other wetland plants and other Schoenoplectus species to seasonal water fluctuations and nutrient increases (Escutia-Lara \& Lindig-Cisneros 2012; Vivian et al. 2014), it is likely that planted and remnant S. tabernaemontanistands would increase in size and extent if lake flows were more variable. A study by Catford et al.,(2014) supports this, suggesting that hydrological regulation in the Murray River system limits the establishment of native plants adapted to variable flows while benefiting more invasive species.

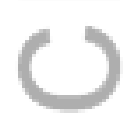

It is unclear from our study how competition from other rapidly growing species such as $P$. australisand T. domingensiswould affect the establishment of new stands of $S$.

tabernaemontanior the potential expansion of planted stands(Tanner 1996; Sainty \& Jacobs 2003; Rogers \& Ralph 2011). For example, P. australisis known to expand rapidly in lake environments at a rate of $2.2 \mathrm{~m}$ per year (Liira et al. 2010). However, increased water depth is likely to be a limiting factor in the establishment of $P$. australis, as submergence is known to limit its growth (Mauchamp et al. 2001; Hayball \& Pearce 2004), whereas $S$.

tabernaemontaniprefers permanent inundation and deeper water environments (Hayball \& Pearce 2004). Therefore, if S. tabernaemontaniis either planted or naturally establishes in deeper water $(50-80 \mathrm{~cm})$, it is likely to outcompete faster growing species such as $P$. australisand T. domingensis(Sainty \& Jacobs 2003).

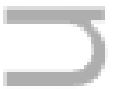

While $S$. tabernaemontaniappears to be relatively resilient to drought conditions, having survived the Millennium Drought and subsequent low water levels byre-sprouting from rhizomes after normal water levels returned to Lake Alexandrina and Lake Albert (Nicol et 
al. 2013), a variety of factors may influence the persistence of this species. These include nutrient increases (Escutia-Lara \& Lindig-Cisneros 2012), droughts and subsequent wetland drying (Catford et al. 2014) and access to the shoreline by livestock and livestock grazing(Vanderbosch \& Galatowitsch 2010). Greater research into how factors such as climate variability, water levels, soil nutrients and lake substrates influence the establishment of sedge species may increase our ability to more effectively restore important wetland systems.

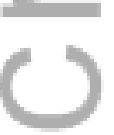

\section{Planting facilitated diversity}

This study suggests that as planted $S$. tabernaemontanistands age, species diversity of associated littoral aquatic plants is likely to increase as time since planting increases. This is supported by other studies that show that plant - plant facilitation can reduce abiotic and biotic stresses in restored habitats, increasing plant survival, recruitment and growth (Zhang \& Shao 2013). In our study it is most likely that planted S. tabernaemontanicaused a breakwater effect, reducing wave energy into the shore andallowing suspended sediment to settle between the planted vegetation and the shoreline (Gedan et al. 2011; Fairweather et al. 2013). This then provided a low energy environment for aquatic plantsto recolonize(Vanderbosch \& Galatowitsch 2010; Nicol et al. 2013).

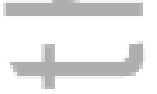

The species we found associated with control sites and young plantings versus old plantings and remnant areas supports this interpretation. For example, many of the plant species associated with old plantings and remnant areas such as Typha domingensis, Azolla filiculoides, Myriophyllum salsugineum, Ceratophyllum demersum and Rumex bidens require 
calm water to become established(Romanowski 1998; Sainty \& Jacobs 2003; Berkinshaw 2009). Similarly, Calystegia sepium requires larger plants to twine around, so it is likely to be recorded in older wetland communities, while Hydrocotyle verticillata prefers calm shallow water environments with a silty substrate (Sainty \& Jacobs 2003). These calm water environments are most likely to occur behind established wetland communities (Berkinshaw 2009) such as those reported here.

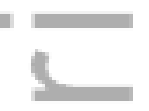

In contrast, aquatic plants associated with young plantings and control sites were usually semi-aquatic, and were more adapted to open habitats(Sainty \& Jacobs 2003). The high incidence of open water in these habitats also suggests that it takes longer than three years for S. tabernaemontaniplantings to form a breakwater effect (Nicol et al. 2013). Thus, old plantings are able to create a low wave energy environment between $S$. tabernaemontaniand the shoreline that allows native emergent, submergent, floating and amphibious species to become established (Sainty \& Jacobs 2003; Nicol et al. 2013). Although young plantings (<3 years) appear to be on a trajectory to providing adequate habitat, it may take up to 8 - 11 years before these habitats start to resemble remnant areas.

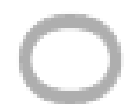

Two of the study sites we sampled did not follow the same trajectory as other sites in similar age-classes. The young planting at Meningie Foreshore contained plant communities more similar to old plantings and remnant areas than control sites or other young plantings. There are two possible reasons for this. Firstly, MeningieForeshore was planted adjacent to an urban area and is likely to have benefited from increased nutrient rich runoff from fertilized recreation areas and private lawns (Tanner 1994; Zhang et al. 2007). Secondly, it is one of the 
older sites in the young planted treatments ( 3 years old), allowing greater time for other plants to recolonize the area between the plantings and shoreline. The old planting at NurraNurra( 9 years old) showed the opposite effect, whereby its associated plant community was most similar to young plantings and control sites. This site, as with other old plantings and remnant areas, survived and regrew from rhizomes after the Millennium Drought (K. Strother, pers. comm.). However, it is thought that NurraNurra remained more exposed during the drought than either Raukkan, Wellington Lodge or Dumandang and thus is taking a longer time to recover (J. Nicol pers. comm.). Although wind-caused seiches may initially influence plant growth and establishment, wind direction and intensity varies (Bureau of Meteorology 2015), making it unlikely that certain sites would be more affected than others.

There are likely to be other benefits of planting S. tabernaemontanialong shorelines that were not reported in this study. Anecdotal evidence suggests that S. tabernaemontaniplantings reduce shoreline erosion(Nicol et al. 2013), and this is supported by other research that shows wetland vegetation is vital in reducing wave attenuation(Gedan et al. 2011). This protects shorelines from erosion resulting from wave damage and increases sediment build-up between wetland vegetation and the shoreline (Gedan et al. 2011). Studies also suggest that old plantings provide adequate habitat for a variety of native fish species as well as mobile invertebrates, rather than planktonic species that are common in open water habitats (Fairweather et al. 2013). Finally, planting species such as S. tabernaemontani is likely to substantially increase carbon uptake in aquatic systems, subsequently reducing the risk of acid sulfate soils during drought years(Moore 2013). 
As other studies have indicated, monitoring of restoration projects is usually minimal(Chapman \& Underwood 2000), with a large-scale study of river restoration projects in the USA finding only $10 \%$ undertook any assessment or monitoring of their restoration activities (Bernhardt et al. 2005). This lack of restoration monitoring may result in a substantial expenditure of funding and resources without the expected benefits of biodiversity or social outcomes. In order to gain a better understanding about how to undertake wetland restoration effectively, and the benefits this restoration has for wetland functionality, a greater amount of funding needs to go into researching and monitoring wetland habitats. This may include increasing links between research institutions, government agencies, community groups and natural resource managers in order to achieve meaningful and cost-effective conservation outcomes. 


\section{Acknowledgements}

This study was supported by the Vegetation Program as a part of the Murray Futures funding from the Australian and South Australian Governments. We would like to thank the Ngarrindjeri Regional Authority and the Ngarrindjeri people for assisting in this project and allowing us to access their land, and also to landowners who allowed us access to their properties. Regina Durbridge from the Goolwa to Wellington Local Action Planning Association assisted in undertaking many of these surveys, as did staff from SARDI Aquatic Sciences. Ken Strother was an invaluable source of knowledge about the history of $S$. tabernaemontani plantings and previous planting techniques. Finally, we would like to thank staff from the Vegetation Program (DEWNR), particularlyEmma Eichler and James Thiessen, who played an important role in planning and implementing many of the plantings around the Lower Lakes.

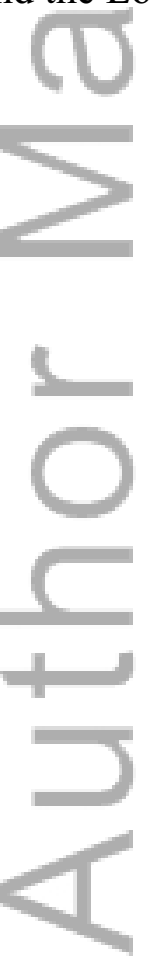

This article is protected by copyright. All rights reserved. 


\section{References}

Anderson MJ, Ter Braak CJF (2003) Permutation tests for multi-factorial analysis of variance. Journal of Statistical Computation and Simulation 73:85-113

Augustin LN, Irish JL, Lynett P (2009) Laboratory and numerical studies of wave damping by emergent and near-emergent wetland vegetation. Coastal Engineering 56:332-340

Bates D, Maechler M, Bolker B, Walker S (2014) lme4: Linear mixed-effects models using Eigen and S4

Berkinshaw T (2009) Mangroves to mallee: the complete guide to the vegetation of temperate South Australia. Greening Australia, South Australia

Bernhardt ES, Palmer MA (2011) River restoration: the fuzzy logic of repairing reaches to reverse catchment scale degradation. Ecological Applications 21:1926-1931

Bernhardt ES, Palmer MA, Allan JD, Alexander G, Barnas K, Brooks S, Carr J, Clayton S, Dahm C, Follstad-Shah J, Galat D, Gloss S, Goodwin P, Hart D, Hassett B, Jenkinson R, Katz S, Kondolf GM, Lake PS, Lave R, Meyer JL, O'Donnell TK, Pagano L, Powell B, Sudduth E (2005) Ecology - Synthesizing US river restoration efforts. Science 308:636-637

Bernhardt ES, Sudduth EB, Palmer MA, Allan JD, Meyer JL, Alexander G, Follastad-Shah J, Hassett B, Jenkinson R, Lave R, Rumps J, Pagano L (2007) Restoring rivers one reach at a time: results from a survey of US river restoration practitioners. Restoration Ecology 15:482-493

Bond NR, Lake PS (2003) Local habitat restoration in streams: constraints on the effectiveness of restoration for stream biota. Ecological Management \& Restoration 4:193-198

This article is protected by copyright. All rights reserved. 
Bond NR, Lake PS, Arthington AH (2008) The impacts of drought on freshwater ecosystems: an Australian perspective. Hydrobiologia 600:3-16

Braun-Blanquet J (1932) Plant sociology. The study of plant communities. McGraw-Hill book company, New York and London

Bureau of Meteorology (2015) Bureau of Meteorology. http://www.bom.gov.au (accessed June 2015)

Catford JA, Morris WK, Vesk PA, Gippel CJ, Downes BJ (2014) Species and environmental characteristics point to flow regulation and drought as drivers of riparian plant invasion. Diversity and Distributions 20:1084-1096

Chapman MG, Underwood AJ (2000) The need for a practical scientific protocol to measure successful restoration. Wetlands (Australia) 19:28-49

Cook RD (1977) Detection of influential observation in linear regression. Technometrics 19:15-18

Crawley MJ (2012) The R Book. Wiley Publishing,

Cumming G (2009) Inference by eye: Reading the overlap of independent confidence intervals. Statistics in Medicine 28:205-220

Cumming G (2012) Understanding the new statistics: effect sizes, confidence intervals, and meta analysis. Taylor and Francis group, New York

Cumming G, Finch S (2005) Inference by eye - Confidence intervals and how to read pictures of data. American Psychologist 60:170-180

DEH (2000) Coorong, and Lakes Alexandrina and Albert Ramsar management plan in South Australia Department of Environment and Heritage, (ed). DEH, Adelaide, South Australia

This article is protected by copyright. All rights reserved. 
Dufrêne M, Legendre P (1997) Species assemblages and indicator species: the need for a flexible asymmetrical approach. Ecological Monographs 67:345-366

Erkkilä HMJ (1998) Effect of different treatments on the seed bank of grazed and ungrazed Baltic seashore meadows. Canadian Journal of Botany 76:1188-1197

Escutia-Lara Y, Lindig-Cisneros R (2012) Dynamics of Phragmites australis and Schoenoplectus americanus in response to the addition of phosphorus and nitrogen in experimental wetlands. Botanical Sciences 90:459-467

Fairweather PG, Whitmarsh SK, Hall SG (2013) Habitat assessment monitoring of revegetated areas in the Lower Lakes: a pilot study in Autumn DEWNR, Adelaide Gedan KB, Kirwan ML, Wolanski E, Barbier EB, Silliman BR (2011) The present and future role of coastal wetland vegetation in protecting shorelines: answering recent challenges to the paradigm. Climatic Change 106:7-29

Gehrig SL, Nichols JM, Frahn KA, Marsland KB (2012) Lower lakes vegetation condition monitoring - 2011/2012, Adelaide

Gehrig SL, Nicol JM (2010) Aquatic and littoral vegetation of the Murray River downstream of Lock 1, the Lower Lakes, Murray Estuary and Coorong. A literature review, Adelaide

Hayball N, Pearce M (2004) Influences of simulated grazing and water-depth on the growth of juvenile Bolboschoenus caldwellii, Phragmites australis and Schoenoplectus validus plants. Aquatic Botany 78:233-242

Hettiarachchi M, Morrison T, McAlpine C (2015) Forty-three years of Ramsar and urban wetlands. Global Environmental Change 32:57-66

This article is protected by copyright. All rights reserved. 
Hilborn R, Mangel M (1997) The ecological detective: confronting models with data. Princeton University Press, New Jersey

Hudon C, Gagnon P, Jean M (2005) Hydrological factors controlling the spread of common reed (Phragmites australis) in the St. Lawrence River (Québec, Canada). Ecoscience $12: 347-357$

Liira J, Feldmann T, Maemets H, Peterson U (2010) Two decades of macrophyte expansion on the shores of a large shallow northern temperate lake: a retrospective series of satellite images. Aquatic Botany 93:207-215

Marsland KB, Nicol JN (2008) Lower Lakes vegetation condition monitoring 2008/09, Adelaide

Matthews GVT (1993) The Ramsar convention on wetlands: its history and development, Switzerland

Mauchamp A, Blanch S, Grillas P (2001) Effects of submergence on the growth of Phragmites australis seedlings. Aquatic Botany 69:147-164

Moore T (2013) Evaluation of carbon storage and potential value of improved ecosystem services provided by the Coorong Lower Lakes \& Murray Mouth Vegetation Program Netpositive, Adelaide, South Australia

Nicol J, Gehrig S, Frahn K (2013) Establishment success and benefits to the aquatic plant community of planting Schoenoplectus validus around the shorelines of lakes Alexandrina and Albert. Data and methods report, Adelaide

Oksanen J, Blanchet FG, Kindt R, Legendre P, Minchin PR, O'Hara RB, Simpson GL, Solymos P, Stevens MHH, Wagner H (2014) vegan: community ecology package 
Pander J, Geist J (2013) Ecological indicators for stream restoration success. Ecological Indicators 30:106-118

Pollard PC (2010) Bacterial activity in plant (Schoenoplectus validus) biofilms of constructed wetlands. Water Research 44:5939-5948

R Core Team (2014) R: A language and environment for statistical computing. http://www.Rproject.org

Roberts DW (2013) labdsv: ordination and multivariate analysis for ecology

Rogers K, Ralph TJ (2011) Floodplain wetland biota in the Murray-Darling basin: water and habitat requirements. CSIRO Publishing

Romanowski N (1998) Aquatic and wetland plants: a field guide for non-tropical Australia. UNSW Press, Sydney

Sainty GR, Jacobs SWL (2003) Waterplants in Australia: a field guide. Sainty and Associates, Sydney

Tanner CC (1994) Growth and nutrition of Schoenoplectus validus in agricultural wastewaters. Aquatic Botany 47:131-153

Tanner CC (1996) Plants for constructed wetland treatment systems: a comparison of the growth and nutrient uptake of eight emergent species. Ecological Engineering 7:59-83 van Dijk AIJM, Beck HE, Crosbie RS, de Jeu RAM, Liu YY, Podger GM, Timbal B, Viney „NR (2013) The Millennium Drought in southeast Australia (2001-2009): Natural and human causes and implications for water resources, ecosystems, economy, and society. Water Resources Research 49:1040-1057

Vanderbosch DA, Galatowitsch SM (2010) An assessment of urban lakeshore restorations in Minnesota. Ecological Restoration 28:71-80

This article is protected by copyright. All rights reserved. 
Vanderbosch DA, Galatowitsch SM (2011) Factors affecting the establishment of Schoenoplectus tabernaemontani (C.C. Gmel.) Palla in urban lakeshore restorations.

Wetlands Ecology and Management 19:35-45

Vivian LM, Godfree RC, Colloff MJ, Mayence CE, Marshall DJ (2014) Wetland plant growth under contrasting water regimes associated with river regulation and drought: implications for environmental water management. Plant Ecology 215:997-1011

Wickham H (2009) ggplot2: elegant graphics for data analysis. Springer New York

Zhang L, Shao H (2013) Direct plant-plant facilitation in coastal wetlands: a review. Estuarine Coastal and Shelf Science 119:1-6

Zhang Z, Rengel Z, Meney K (2007) Nutrient removal from simulated wastewater using Canna indica and Schoenoplectus validus in mono- and mixed-culture in wetland microcosms. Water, Air, and Soil Pollution 183:95-105

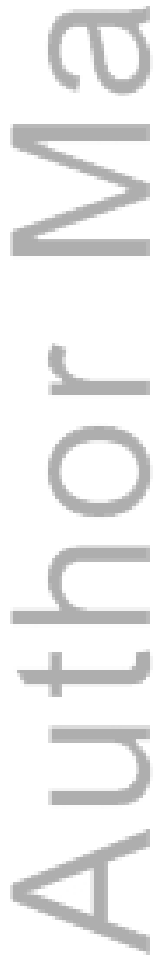

This article is protected by copyright. All rights reserved. 
Table 1. The aquatic plant species associated with each cluster group: Cluster 1 - young planting, control and one old planting (NurraNurra), Cluster 2 - Remnant sites, old plantings, one young planting (Meningie Foreshore). * Introduced species, V = vulnerable (National Parks and Wildlife Act 1972, Schedule 8), R = rare (National Parks and Wildlife Act 1972, Schedule 9).

\begin{tabular}{|c|c|c|c|}
\hline$=$ Species & Cluster & $\begin{array}{l}\text { Indicator } \\
\text { Value }\end{array}$ & Probability \\
\hline Open Water & 1 & 0.539 & 0.095 \\
\hline Cenchrus sp.* & 1 & 0.163 & 1 \\
\hline Isolepisproducta $(\mathrm{V})$ & 1 & 0.143 & 0.522 \\
\hline Nitella & 1 & 0.083 & 1 \\
\hline Cotulacoronopifolia & 1 & 0.076 & 1 \\
\hline Crassulahelmsii & 1 & 0.071 & 1 \\
\hline Limosellaaustralis & 1 & 0.071 & 1 \\
\hline Juncususitatus & 1 & 0.071 & 1 \\
\hline Calystegia sepium & 2 & 0.852 & 0.001 \\
\hline Typha domingensis & 2 & 0.829 & 0.001 \\
\hline Schoenoplectus tabernaemontani & 2 & 0.731 & 0.003 \\
\hline Azolla filiculoides & 2 & 0.714 & 0.004 \\
\hline Paspalumdistichum * & 2 & 0.671 & 0.024 \\
\hline Myriophyllum salsugineum & 2 & 0.668 & 0.008 \\
\hline Phragmitesaustralis & 2 & 0.607 & 0.042 \\
\hline Ceratophyllum demersum $(\mathrm{R})$ & 2 & 0.571 & 0.006 \\
\hline
\end{tabular}

This article is protected by copyright. All rights reserved. 


\begin{tabular}{llll}
\hline Ranunculus trilobus* & 2 & 0.571 & 0.004 \\
Rumex bidens & 2 & 0.562 & 0.004 \\
Trifolium sp. * & 2 & 0.429 & 0.026 \\
Persicarialapathifolia & 2 & 0.429 & 0.035 \\
Berulaerecta * & 2 & 0.429 & 0.038 \\
Mentha sp. & 2 & 0.429 & 0.026 \\
Lemna sp. & 2 & 0.429 & 0.028 \\
Hydrocotyle verticillata & 2 & 0.429 & 0.029 \\
Bolboschoenuscaldwellii & 2 & 0.388 & 0.046 \\
\hline
\end{tabular}

This article is protected by copyright. All rights reserved. 


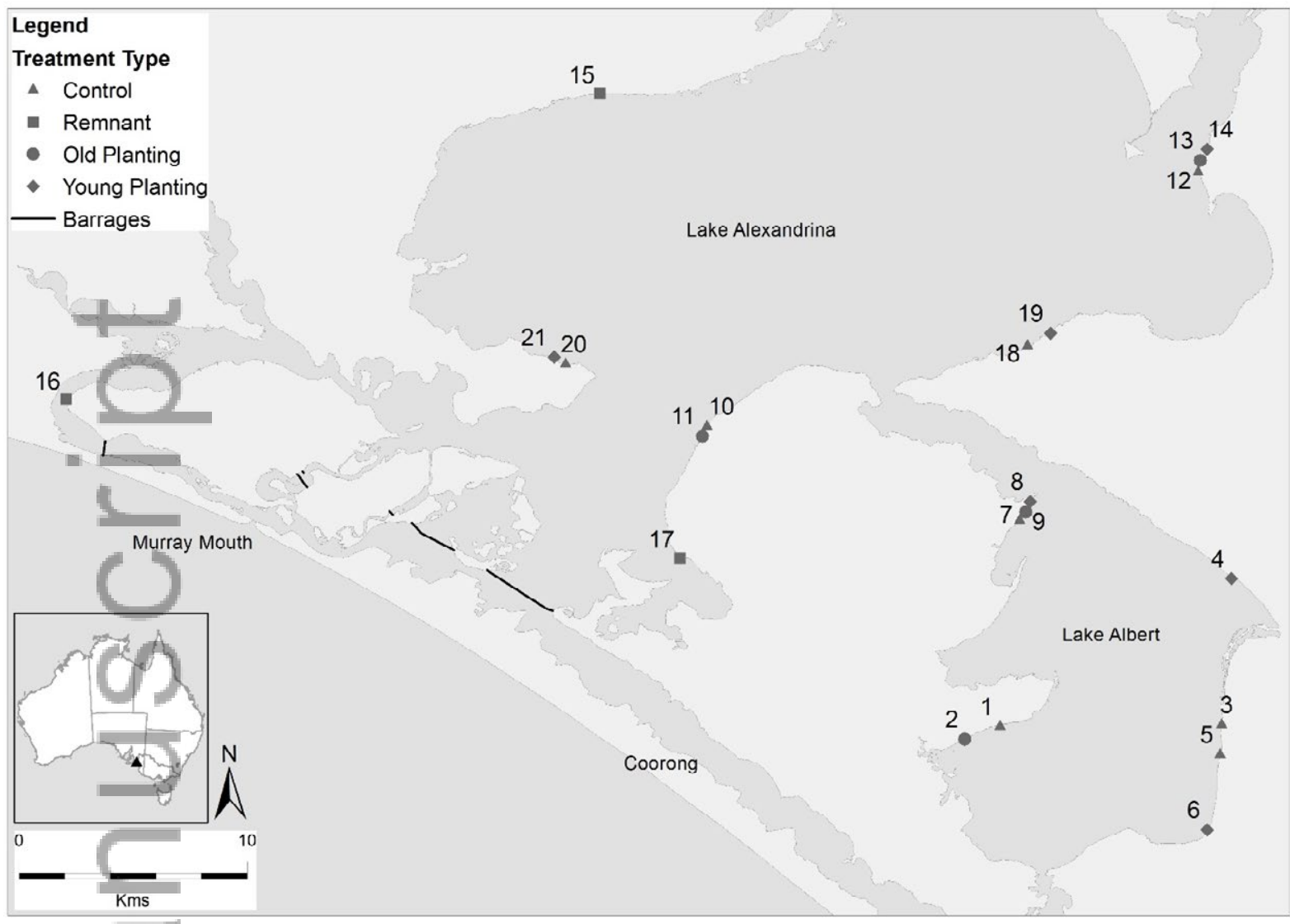

Fig 1. Sites surveyed between 2013 - 2015 in Lake Alexandrina and Lake Albert, South Australia. Numbers represent site treatment IDs (Table S1)

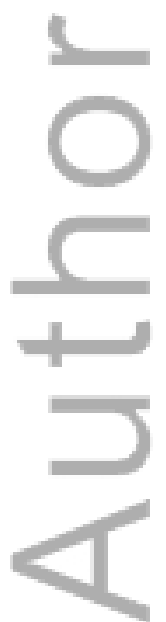

This article is protected by copyright. All rights reserved. 
$100 \mathrm{~m}$ section of shoreline (0.75 AHD)
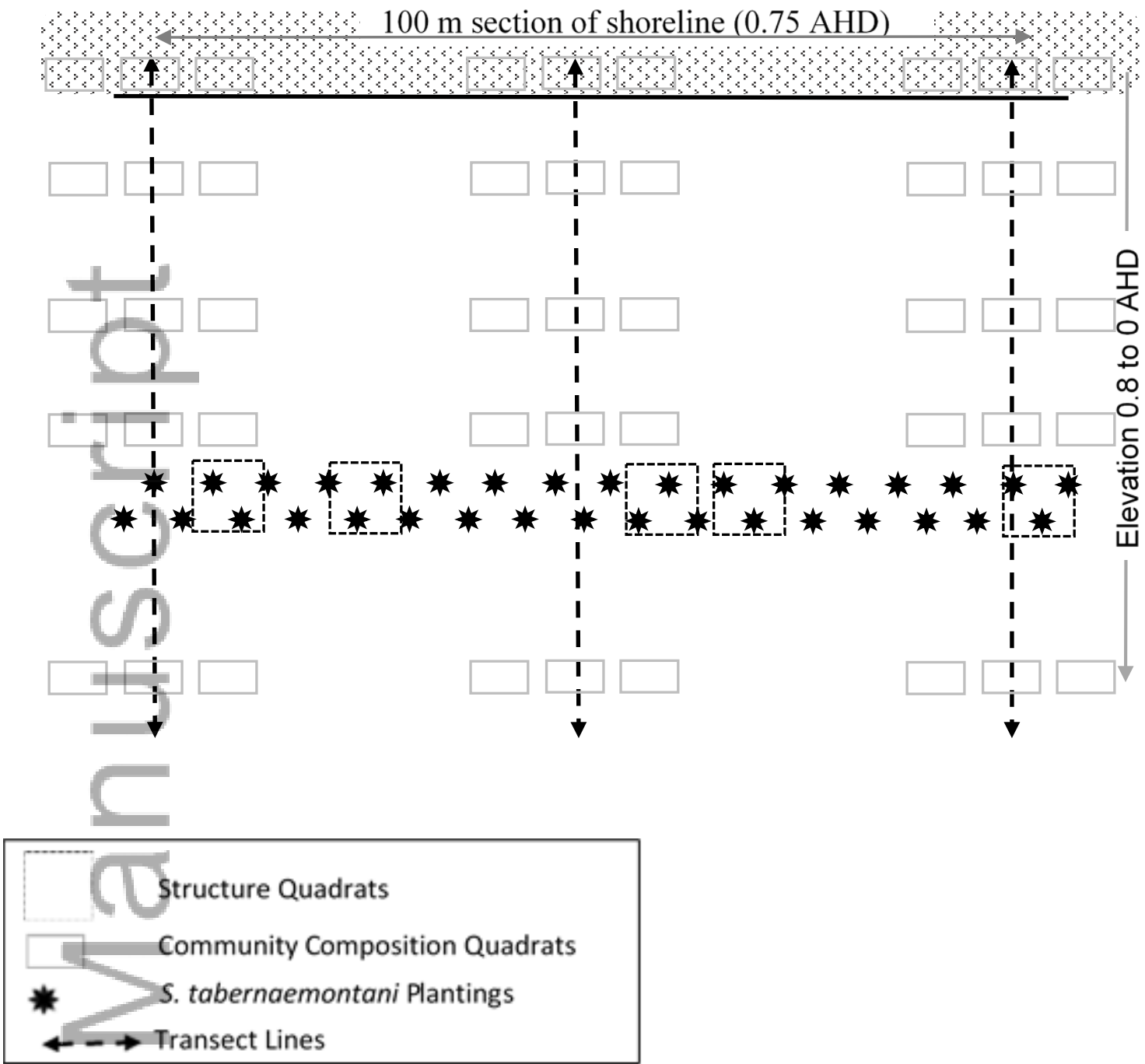

Fig 2. Layout of quadrats to determine the community composition of planted $S$. tabernaemontanisites, remnant S. tabernaemontanisites and control areas. Structure quadrats were also undertaken in planted and remnant $S$. tabernaemontani sites.

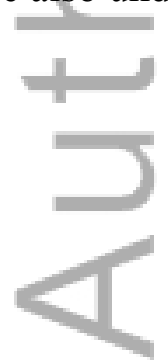

This article is protected by copyright. All rights reserved. 


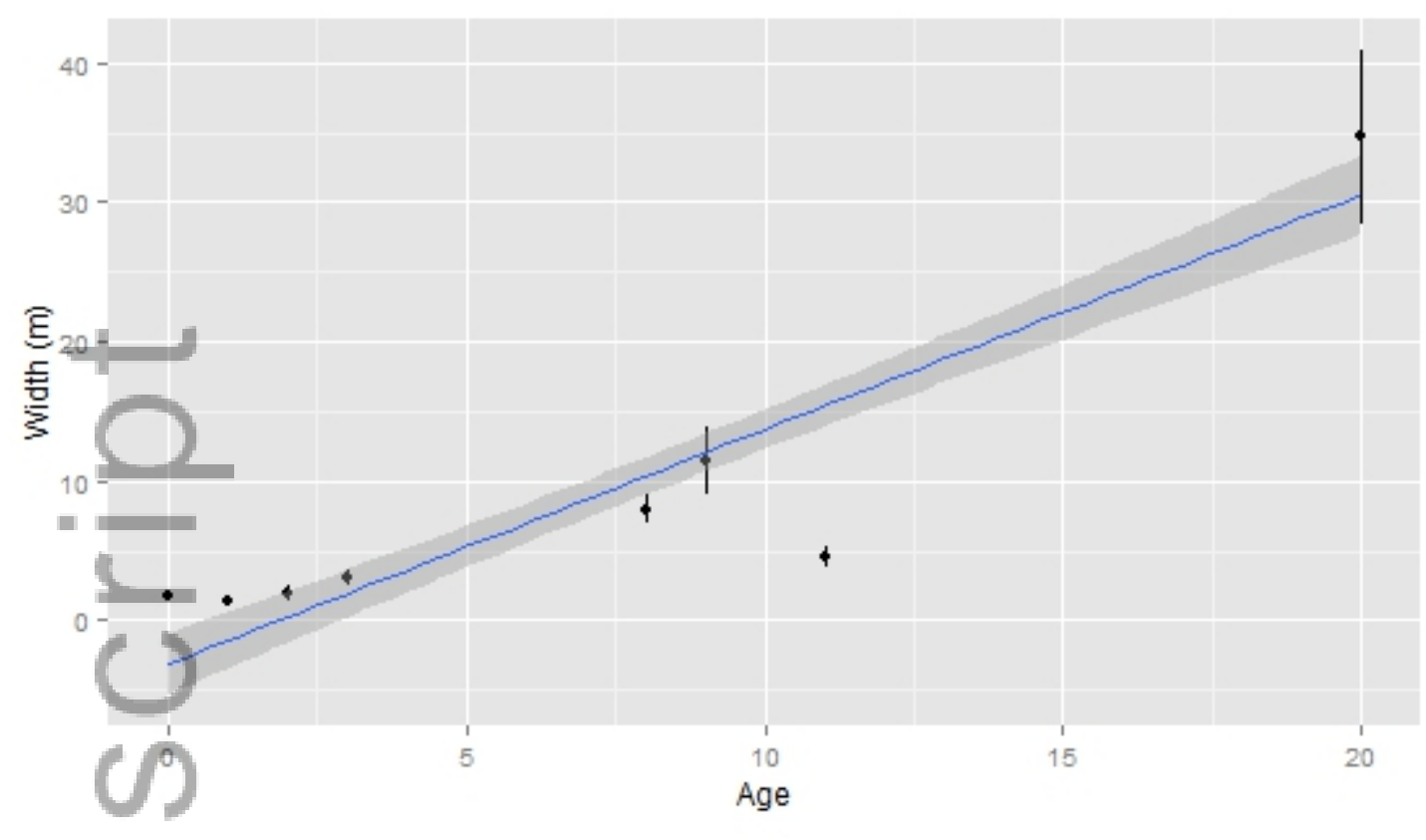

a)

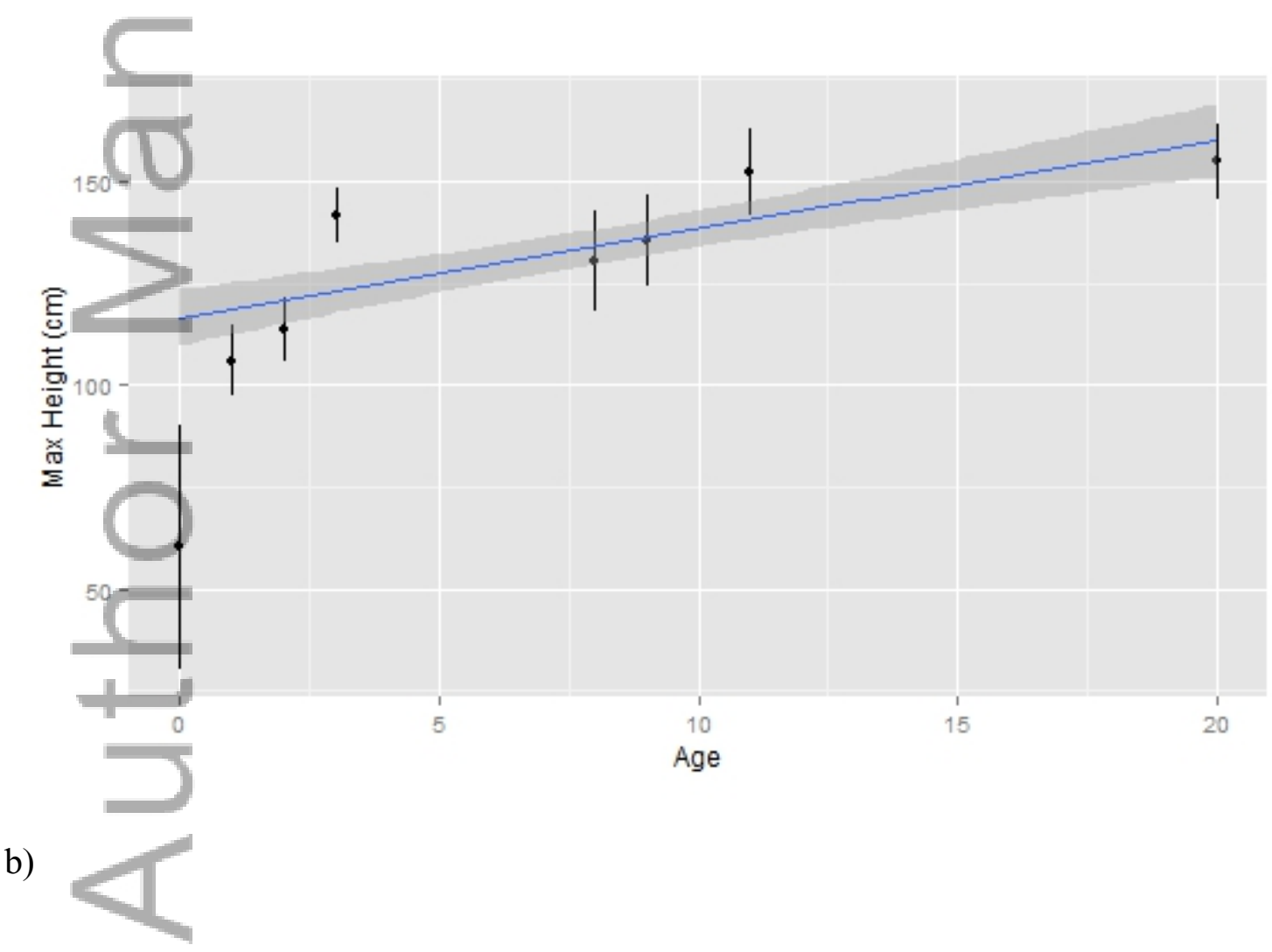

This article is protected by copyright. All rights reserved. 
Fig 3. The influence of planting age (young plantings $<1-3$ years of age, old plantings $8-11$ years of age, and remnant areas that were all given an age of 20 years) on Schoenoplectus tabernaemontani(a) stand width and (b) maximum stem height. Bars represent $\pm 95 \%$ confidence intervals. Shaded band around regression line represents a 95\% confidence region.
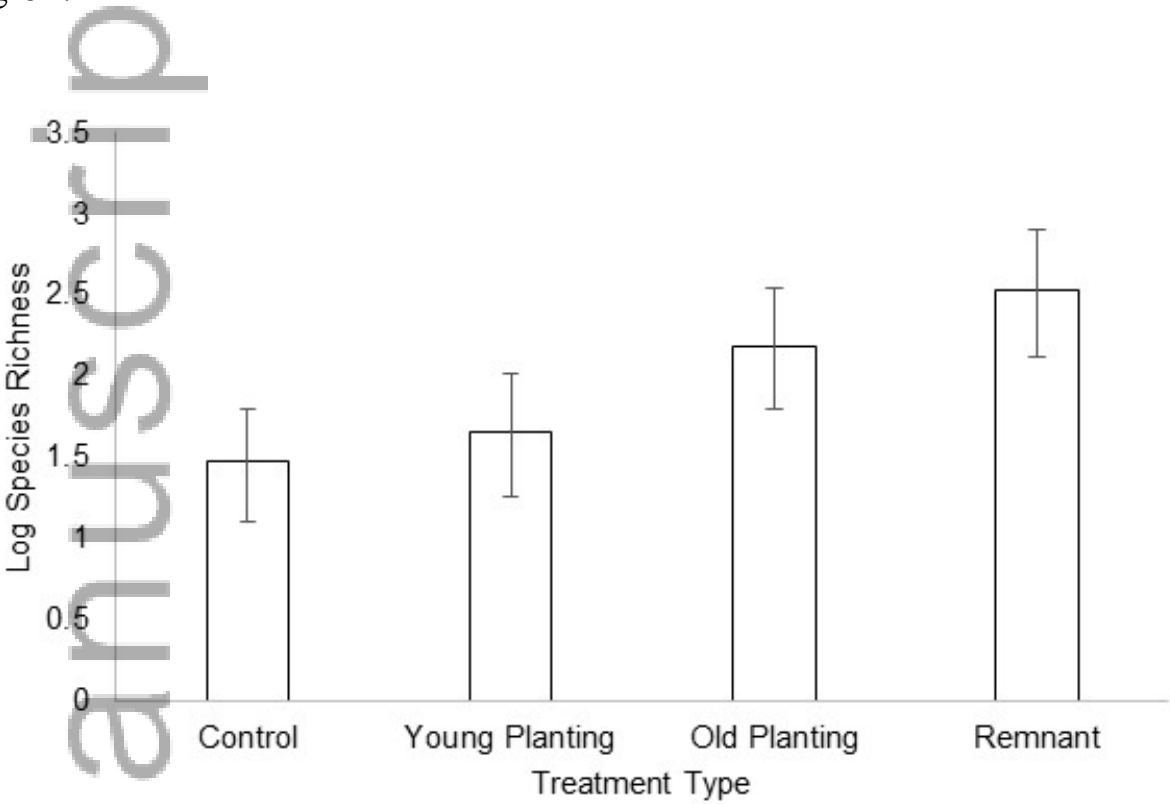

a)

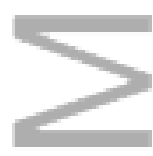

Treatment Type

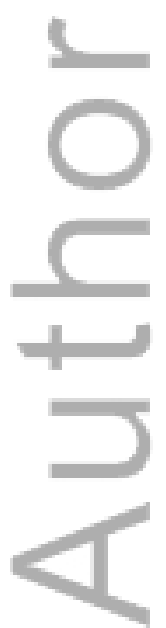

This article is protected by copyright. All rights reserved. 


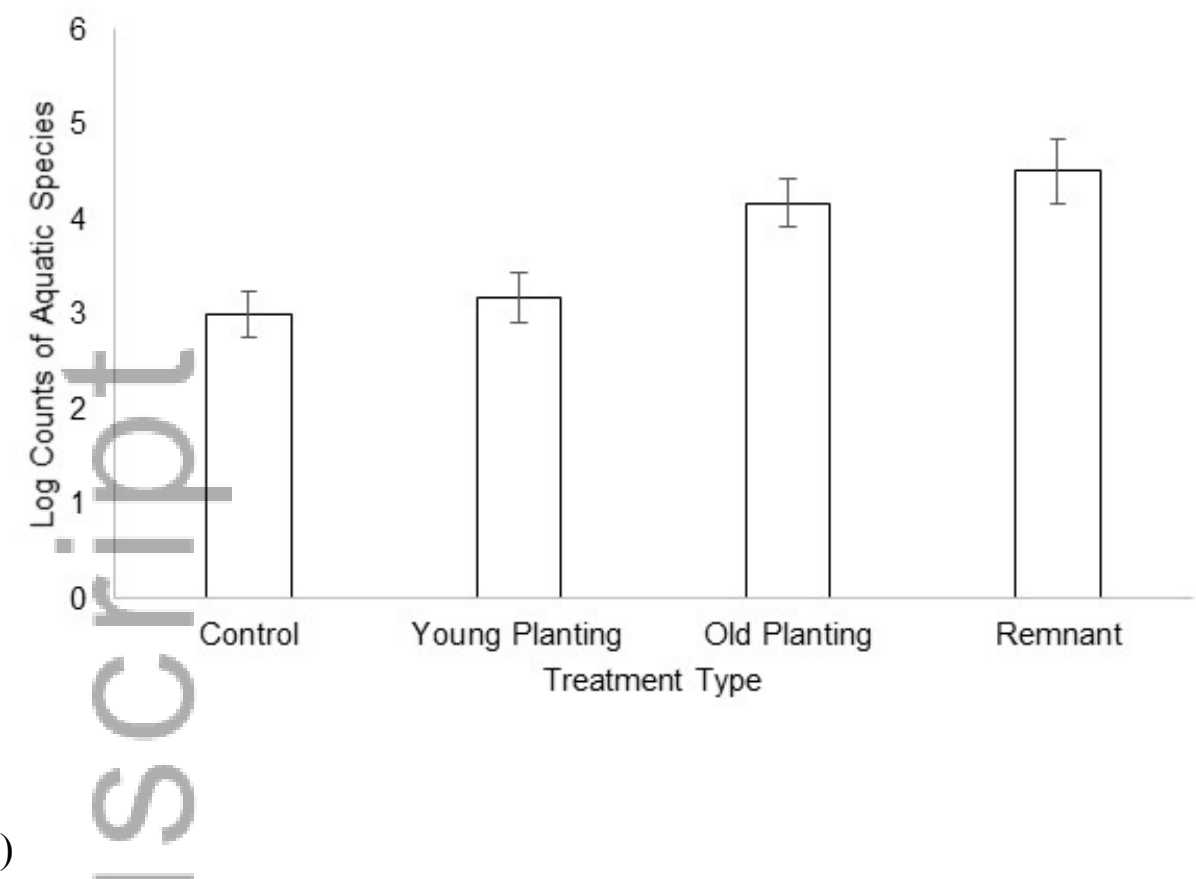

Fig 4. The log species richness (a) and counts of aquatic plant species (b) found in different treatment types around Lakes Alexandrina and Albert. Bars represent $\pm 95 \%$ confidence intervals.

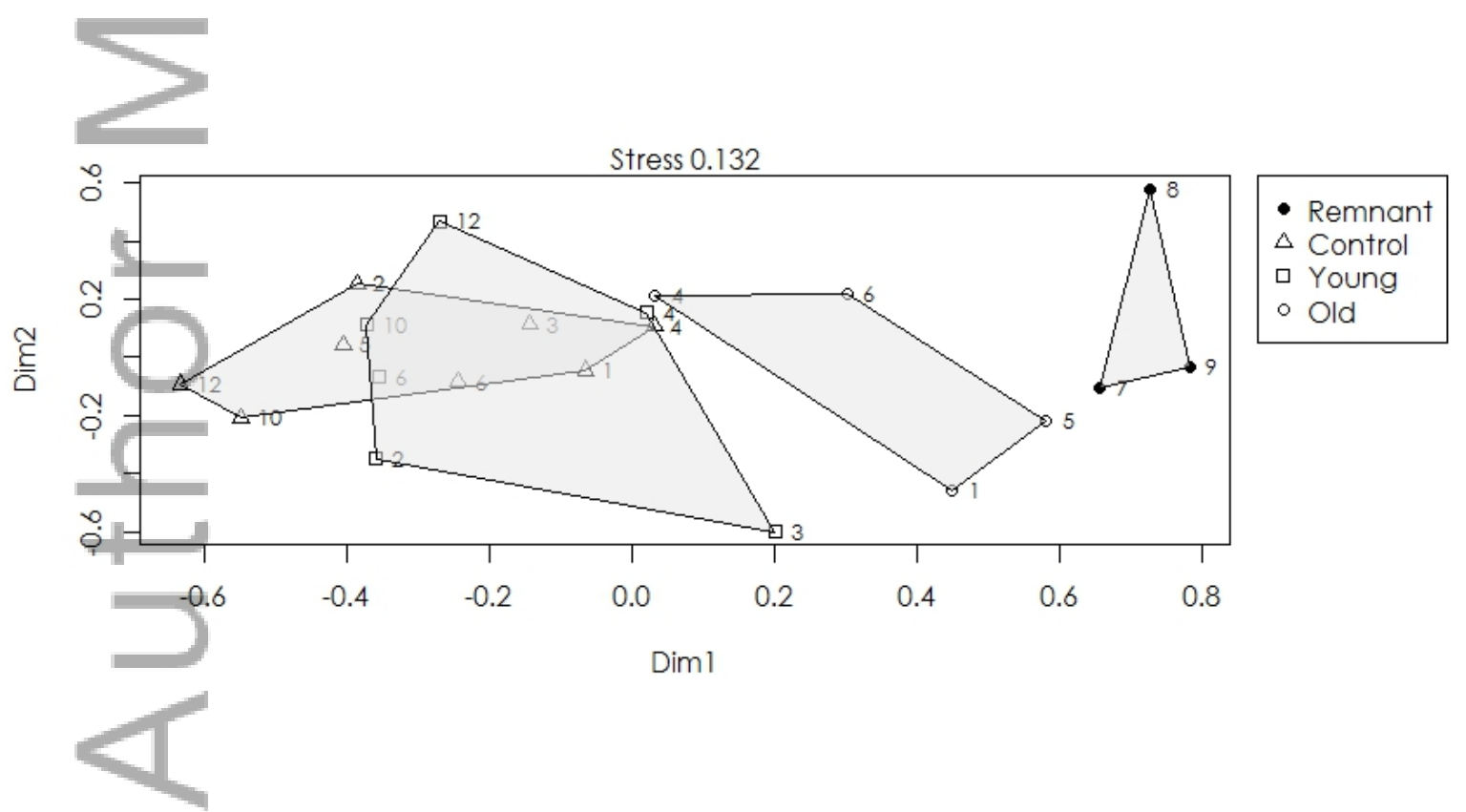

This article is protected by copyright. All rights reserved. 
Fig 5. A two dimensional plot of aquatic plant community composition in the four treatments surveyed. Numbers represent Site IDs (Table S1).

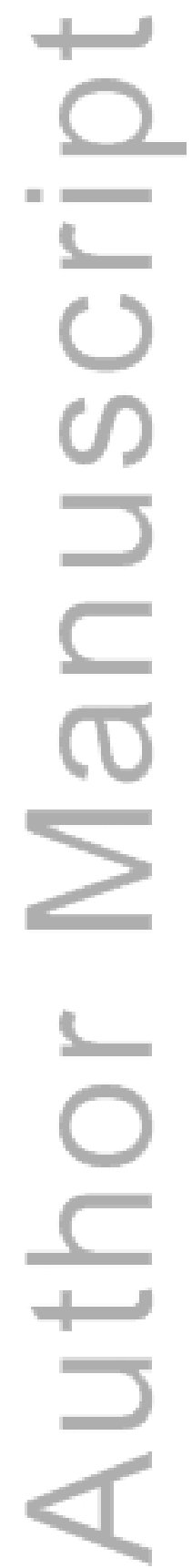

This article is protected by copyright. All rights reserved. 


\section{University Library}

\section{- M M N E R VA A gateway to Melbourne's research publications}

Minerva Access is the Institutional Repository of The University of Melbourne

Author/s:

Jellinek, S;Te, T;Gehrig, SL;Stewart, H;Nicol, JM

Title:

Facilitating the restoration of aquatic plant communities in a Ramsar wetland

Date:

2016-07-01

Citation:

Jellinek, S., Te, T., Gehrig, S. L., Stewart, H. \& Nicol, J. M. (2016). Facilitating the restoration of aquatic plant communities in a Ramsar wetland. RESTORATION ECOLOGY, 24 (4), pp.528-537. https://doi.org/10.1111/rec. 12355.

Persistent Link:

http://hdl.handle.net/11343/291149 